\title{
Analysis the Hidden Advantages of Written Pretests for Student Intelligence
}

\author{
Ali Taufik ${ }^{1, a^{*}}$, Suid Saidi ${ }^{1, b}, \&$ Tatang Apendi ${ }^{1, c}$ \\ 1Department of Education and Technology, Faculty of Teachers Training and Education, Kutakartanegara University, Tenggarong, 75513, Indonesia \\ a alfiforever@gmail.com; b suidsaidi2@gmail.com; c tatangukt@gmail.com \\ *Corresponding Author \\ Whatsapp number: [+628121566444]
}

How to Cite : Taufik, A., Saidi, S., Apendi, T. (2019). Analysis the Hidden Advantages of Written Pretests for Student Intelligence. International Journal for Educational and Vocational Studies, 1 (7), 713-718

\section{ARTICLE HISTORY}

Received: 13 July 2019

Revised: 19 August 2019

Accepted: 26 September 2019

\section{KEYWORDS}

Pretest;

Qualitative;

Learning;

Intellegence;

Students;

\section{ABSTRACT}

This study is starts from the concept of oral pretest, which is almost always monotonous, often carried out by teachers or lecturers when conducting teaching and learning activities in front of the class so that oral pretest is only considered a question that is not too important by students. The author tries to do research using written pretest, the aim is to improve, sharpness, thinking patterns, understanding, and intelligence. This can be done for all students as a whole, with only around 10-15 minutes, when discussions about new lessons begin, it turns out that there is a significant increase in students' understanding and intelligence.

This is an open access article under the CC-BY-SA license.

\section{INTRODUCTION}

The background of this research is to try to develop the concept of pre test oral typically performed by teachers and lecturers at the start of teaching and learning activities, namely the initial test (pretest) is usually performed to measure the random ability of students and aimed only at a few people, so that when be less effective, the reason is limited to teaching time taken by the pretest (initial test) .pretest or scratch test is actually the media to ask the student, by teachers and lecturers to the students, to explore patterns of thought and how far the students' understanding and students, the answer of his students have described the level of intelligence and understanding.

According to (Schneider, 2013), in his thoughts on methods Methods ask is the method used Socrates, and this is one way of belonging to the model of discovery, and this is due to the character and model of the questions Socrates probing to get the validity of the answers Then the question Socrates student also is more scientific and focused, so that When viewed from the development of the discovery method, then turned into a pretest in the world of education and used as a learning method. The actual method of pretest is also known among the scientific world more and not only in education and teaching, for example among paramedics, social workers and marketing, as said
(Dimiter et al., 2003) Pretest-posttest design is widely used in behavioral research, especially for the purpose of comparing groups and/or measuring changes resulting from the experimental, this proves how useful the implementation of the pretest and posttest was done.

Then other opinions are still among medical schools, from (Shivaraju, et al., 2017) Pre-test and post-test are used to measure the knowledge gained from in training courses. Active learning strategies, including students involved in activities (reading, discussing, and writing) that involve more than understanding and learning, greater emphasis is placed on developing students' skills.

In implementing pretest written teacher or lecturer must be serious and when evaluation, problems sometimes arise when the pretest is only a cursory trial, as said (Schaffhauser, 2018), but teachers and students are often confused about the "voluntary nature" of the pre-test, where questions require answers, including questions that may not be answered by students, when filling out a questionnaire or survey. Therein lies the problem, sometimes being half apathetic students in answering pretest questions, it must be motivated that the pretest is included in the assessment, so students/students do it responsibly. 
Teachers and lecturers to improve students' knowledge and understanding, what must be done is an evaluation of written pretests, and not oral achievements, which so far have often been done by teachers and lecturers. The purpose of this study was to determine the benefits of written pretests, because so far the Teachers and Lecturers only perform oral pretests, and are very monotonous, and tend to be less purposeful. The author conducted a research experiment using a written pretest, when starting the lesson. According to, (Kelly, 2019) At each grade level and in every discipline, the teacher needs to find out what students know and can do before starting a new study unit. One way to make this determination is to use pre-tests that assess students' skills in the skills that will be taught in one unit.

Opinion (Shiva, 2017), said that pre-tests were given to participants before they started training as a tool to measure how much they already knew about the topic $/$ problem or concept to be discussed in this study. At the end of the training, participants complete a post-test that measures their ability to apply knowledge or perform certain tasks learned in learning. By conducting a written test on the pre-test, the author can find out how deep the level of understanding of students, in individuals. The pretest model (initial test) using this writing system will make it easier for teachers and lecturers to rank/classify individual students, in the assessment of understanding with teaching material to be presented, and more precisely on target, the questions in this test are also not many in just two or three questions, with 10-15 minutes is enough, but all students can take part in this evaluation.

To measure the student's intellegence level of pure, do a written pretest, and before the topic of the lesson is taught, the answers of these students will train the level of intelligence and understanding of students, and students will be eager to learn early (Studying at Home).The general function of a pretest is to evaluate an activity or program before the implementation of an activity, and then the pretest is also a media measuring the level of understanding and intelligence with learning activities that have not been implemented.

Definition of pretest of (Hilton, 2015), Pretesting is a method to check whether a question functions as intended and understood by those who tend to answer it improperly. However, detailed reports of appropriate methods for conducting pretests are currently under-represented in the literature. Hilton's definition could mean that pretesting, lacking attention from educational practitioners, the authors agree with Hilton that the evaluation position on the pre-test (written pretest), less attention from education practitioners.

Pretest according to (Chabot et al., 2014) "Evaluation of the pretest and posttest is one of three assessment tools that are highly recommended for use by the faculty because this is a concise and very good direct evaluation that creates a rational dialogue to improve performance and the quality of student learning, one of which is recommended by Costa is the pretest, which is being researched.

Function tests specifically means tests conducted for the assessment of a formal activity such as in schools, courses, administration whose objectives are sustainable and one form of tests in schools is a pretest that is carried out before learning is carried out, the benefits of determining the level of students Understanding of the field of field followed, before the teaching and learning activities carried out.

According to (Berry, 2008), Re-test or pre-test can be used at the beginning of the lesson to build a knowledge base related to the subject and then at the end of the lesson to see that less knowledge can be added. Pre-tests can also be used as a way to assess the depth of understanding needed. Then, according to (Sudijono, 1996) pretest conducted to determine the extent to which subject matter or material, which will be taught must be mastered by students. In processing exam questions, as well as in carrying out pre-tests and understanding them, then pretest according to opinion (Delucchi, 2014), the increase in pretest-posttest knowledge is more influenced by the content and presentation of social statistical learning.

Written pretest is able to improve students' understanding and intellectuality, the teacher and lecturer to implement the program, so that the pretest evaluation is more beneficial. According to (Purwanto, 1999), media measurement pretest is given before starting teaching with the aim to find out, to which the student's mastery of the instructional materials that will be taught.

In another opinion about the pretest of (Beckman, 2008), Pre-tests are commonly used to determine whether students have the prerequisite skills necessary for teaching units that will come, or the extent to which the student has achieved the purpose of instruction planned. Excerpt of Beckman's opinion, can be defined how the students could prepare him with questions pre-test, the teacher or lecturer, but Beckman does not explain what pratest used models, oral or written, or both digunakandalam pratest it.

Function pre test and post test in evaluation. Pretest performed before a teaching activity carried out to measure the level of achievement in the material that has not been served whereas while the post-test performed after the subject matter presented, was here the author doing research on pretest written, in excerpts opinion (Mulyasa, 2008), the pretest is to prepare students in the learning process, because of the pretest and posttest then their thoughts will be focused on a matter that they have to do In doing pretest written that really needs attention is the form of questions, in order to give students a pattern of deep thinking to answer, although the time is short, insightful questions to be able to become a standard assessment for measuring the level of intelligence of students, including understanding of the material that will be in teaching.

According to the opinion (Novianti \& Salim, 2018), Readiness to perform learning is an important thing. Success or failure of the learning process begins with readiness and completeness before and at the time of learning. Learning readiness can of readiness of the 
teacher, could also readiness of students, so does the success of teaching is also inseparable from the students themselves apart innovation of Teachers and Lecturers in classroom management.

Opinions (Shivaraju, et al., 2017) Pre-test and post-test was used to measure the knowledge gained from participating in training courses. Active learning strategies include students involved in activities, Reading, discussing, and writing), ie, is involved in more than listening passively, greater emphasis is placed on developing the student's skills. Pretest verbal methods-effective means that can be done by teachers and lecturers, to evaluate if this is implemented with programmed and sustained, the results will be visible at the time of the evaluation study/test summative or final exams (UAS).

\section{METHODS}

This research deepens and understands the documents to be analyzed, namely the student's answer sheet as a result of the answers at the written pretest. The pretest evaluation of the study used a qualitative method type of document study, the qualitative research was a direct observation approach in opinion,according (Sugiyono, 2009), it was in the researcher, must study a qualitative approach falls spaciousness, as researchers is an important part of the instrument itself.

Definition according Philip Mayring in a paper with the theme of Qualitative Content Analysis argues (see Moleong, 2007) In a research study of the document there are four steps that need to be considered by the investigators (content analysis), 1. Adjust in communication model, 2. Set analysis incrementally, as the procedure, that is to divide the material into the form of units, 3.Kategory as the center of analysis, 4.Criteria, credibility and validation.

In the definition of the opinion document (Sugiyono, 2005)), that the document can be shaped with: writing, drawing, monumental works, videos, letters and documents state ( archives).

\subsection{Participants and Data Location}

Place of research at the University campus kutaikartanegara, Kutaikartanegara Regency, East Kalimantan, while the participants are some of the students of class B, amounting to twenty-six (26), on the Educational Technology Studies

\subsection{Data Instrument}

Instrument of data used during this study in addition to observation is, interview techniques, sheet test questions and the questionnaire questions in supporting research activities, according to (Sugiyono, 2014), The purpose of these interviews is to find the point of the problem to be more open where those parties are in encourage voluntary interviews need to be asked for their opinions accuracy of researchers who are doing research in a listen and record information from informants or participants who are interviewed at the time.

In another opinion about the instrument according to (Azwar, 2015) In the development of a measuring instrument, commonly used test for measuring instrument mentions cognitive ability, while the more widely used scale for measuring instrument called non-cognitive attributes

\subsection{Data Collections}

Data collected from the question sheet pretest written, apart from the question sheet is also the author gives a sheet questionnaire in the form of questions before the research is completed but not all students are given a questionnaire only student authors have recruited as participants with a single criterion, namely student / participant is able to achieve best value which is five the participants when the study is over, because the data sampling is also necessary to add information from the participants, about the response, a written assessment of the pretest, in this case the authors use the model of purposive sampling (questionnaire given to a limited scale)

According to opinions (Nasution, 1982), says that a qualitative method using the sample selection based on objective research, and samples taken tends to be a bit of (limited) Qualitative research is often the form of case studies or multiple cases but referred to as a social situation that consists of three elements; place (place), actor (perpetrator), and activity (activities), which means that the sampling be used instead for the overall population.

The writer is a researcher, as well as the subjects used as a research question is a course that authors as instructors in the semester, so in terms of the analysis of the data can be processed after lecture hours completed, and then the next week will be followed by instument another question, according with the subject.

After the author made the instrument questions related to teaching materials that will be presented, then write on the board (can also be read out directly), and the students write questions on a piece of paper, wrote their names, then answered the question by the time given $10-15$ minutes, with a two-question pretest evaluation enough even written completed and collected, then the lecture continued as usual until the time is completed, if there is still time to do postest orally or in writing.

\subsection{Data Analysis}

Perform data analysis with the results of the written response of the students after the pre-test is complete, corrected scores top marks, medium and lower than the standard value that is, about answer its authors use a range of numbers with the highest score (60-100), with a percentage (60\%-100\%) the answer either in accordance with any questions given. For score enough (30-50), with the percentage (30\%-50\%), when the answer to the question given. then according to the level of a low score (10-20) with 
percentage $(10 \%-20 \%)$, when the answer is less/not suit to a given question.

Regarding figure score is not tied to please the teachers and lecturers use the scores and the criteria with the level number, respectively, as a function scores here make it easier to sort out the depth of intelligence and understanding of students with subjects or subject areas that have not been implemented by the Teacher or Lecturer, so it can be evaluated with pure data retrieved earlier written pretest.

The questions made in the written pretest evaluation must be in accordance with what has been taught so that the level of validity can be measured, and the implementation time is also not difficult, because it is in accordance with the lecture schedule in one semester. In one semester there are 16 meetings, use 12-14 meetings to evaluate for the written pretest.

\section{RESULTS AND DISCUSSION}

\section{Results}

After analyzing the results of the research during the two meetings, using the written pretest at the beginning before teaching, and the authors saw significant progress for student intelligence.

Let's look at 12 of the results or benefits of using written pretests on students and teachers or lecturers.

\section{Advantage For Students.}

Students are more eager to learn early (study at home) Students have a positive spirit of competition or competition

- Students are trained in the development of imagination, to answer questions.

- Students take the test seriously.

- Students are able to build learning characters.

Students are trained in answering questions independently.

\section{Adavantage for Teachers and Lecturers.}

Teacher/Lecturer can do a written pretest with all students.

Teachers/Lecturer, has a questions file (Questions bank).

- Teachers/Lecturers, can know the level of student understanding entirely

- Teacher/Lecturer, only takes 10-15 minutes, (at the beginning of the lesson)

- Teacher/Lecturer, have enough time to correct student answers.

Teachers/Lecturers can find out cognitive, apective and psychomotor students even though the UAS (exam) has not been carried out. Can be seen fluctuations in score values each item (High, Medium and Low), of course this can't be taken standard, because the final score of the participants, increasing a major in the field of understanding and decipher the question of pre written test the research can be said to be successful when the score low is getting more reduced, and a high score being as well as increasing

In this study, the authors have also included the results of interviews and questionnaire answers of the five participants who were selected after data reduction and data analysis, then selected five participants whose value is highest and were given a questionnaire to fill out, in this case I want to know the response of the evaluation pretest written the participants of five people, this would be the answer to an interview and answer a questionnaire of five participants who were already in a reduction in narrative form, in order to more easily understand $\mathrm{i}$

The following results:

Participants: 1 (One)

Name: BS (inisial

Status: Student

20 years old.

Feedback on the pretest written: " As a student I love pretest written, although initially a bit heavy in answering the question, but it makes me excited to learn before college so I can answer the questions " (interviews and answers to questionnaires, date December 17, 2018).

Participants: 2 (two).

Name: IP (inisial)

Status: Student

20 years old

Feedback on the pretest written: "At first I was confused to answer anything, because it has not been studied, but after the next meeting I learned first and try to understand it, and I finally got used to the way of learning as it " (interviews and answers to questionnaires date, February 17, 2019)

Participants: 3 (Three)

Name: LA (inisial)

Status: Student

Age: 21 years

Feedback on the pretest written: " Usually it's oral test, but I was challenged to answer these questions, and made me want to learn before the lecture held " (interviews and answers to questionnaires, dated February 17, 2019).

Participants: 4 (Four)

Name: AR (inisial)

Status: Student

20 years old

Feedback on the pretest written: " I can not answer the question, I just write estimates only about the content of the question, the next meeting I learned to understand the question, and made me to be ready before the lecture held " (interviews and questionnaire answers dated February 10, 
2019)

Participants: 5 (Five)

Name: SA (inisial)

Status: Student

20 years old.

Feedback on the pretest written: " Previously I think the test is difficult, because it has not been taught, but with practice thinking how to understand, finally I can answer that question, though not very relevant, because only by my own thoughts " (interviews and answers to questionnaires date,10 February,2019)

From the results of answers to the interview and questionnaires that have been in the reduction and analysis shows that the five participants beginning it was a bit difficult because the material of lectures is not taught, but after the next evaluation of the participants have started to understand and prepare before the lecture, this is certainly a case very nice, with indirectly motivate the students themselves, it is proved by the results of the written test conducted pretest scores increasing its value (see the results of a meeting scores to 12)

\section{CONCLUSION}

From the research that has been done, it was found written pretest able to increase the value of intelligence and understanding, on the course or field of study that follows, here students are invited to make predictions about the content of the course is to be taught, by answering questions from the written pretest

Why pretest at school or in college is done mostly with pretest " verbal "?, Although it is less effective, because the question can't be done with the whole student, then also questions uncontrolled standard difficulty, then the question is sometimes lost, because rarely Teachers and Lecturers archive these questions, the time is also sometimes less effective and are not controlled (can be more than 10-15 minutes)

Now let's compare it to taking a written pretest system the question of control, limited time for example 10-15 minutes then, all students can follow it, the difficulty level of questions/inquiries already measured, about the matter of the question can be filed (Bank matter), then from the psychological side of students will arise the motivation to learn, understand, study, prepare themselves, then predicts and outlines have their own abilities in question, students still fairly low intelligence level will be motivated to rise the level above, there will be healthy competition in increasing motivation of learning for students itself, because this research only about twelve times the face of very short to conduct more in-depth research,but from the results achieved already seen there is a significant enhancement towards better

In pretest written this in addition to understanding the studied course also intelligence and thought patterns, because the understanding and intelligence of the interconnections, as expressed by (Campbell, 2002),
Interpersonal intelligence is the main factor that determines students acquire the learning outcomes of social science as well or not. Students yng has a low level of interpersonal intelligence would be difficult to control yourself

The concept of the implementation of the method pretest written is indeed necessary seriousness of education actors in this case Teachers and Lecturers for the implementation of the required diligence, patience evaluation and correction to answers the learners, and when done with sincerity the results will be seen, it can be seen of the rise in results the best answer after this research

These results show and prove the importance of the written pretest position that must be done by teachers and lecturers in all teaching and learning activities carried out, see the results of this study the effect of pretest written to improve students' understanding and intelligence in schools and elementary schools, because students are challenged to learn to understand which has not been studied, so that it is different from the formal system, students learn after learning.

In the opinion (Goleman, 2015) Intelligence is ability as the ability to motivate oneself and fight frustration, control impulses and not exaggerate pleasure; regulate mood and maintain stress loads so as not to be paralyzed. So actually the level of intelligence, then someone will be able to control himself (his emotions).

Related to the level of intelligence and understanding of pretest written is one medium that is a good thing to do, but lack of attention, opinion (Hilton, 2015), that pretesting is underrepresented in the development of even very little literature that discusses the pretest, namely the author agrees with an opinion, this is one reason for the author to test the pretest, with development in written form, which is very rarely done even the author has never had empirical experience during school, or while studying in college.

In this study the author has difficulty finding references to problems related to the development of pretest in writing, to the field of teacher education and training, especially the results of previous studies, especially on the written pretest, this is one weakness in this matter. problem. study, so that the development of data and sources of information in this study, the author has a more empirical experience, as an educator.

Suggestions for school institutions /education, can be developed in each school, for example in one semester using written pretest before learning activities are carried out, for other researchers can deepen this written pretest research, because good research always develops and finds new things is beneficial to humanity.

\section{REFERENCES}

Azwar, S.,(2015). Penyusunan Skala Psikologi (Vol.2). Yogyakarta: Pustaka. Belajar. 
Beckman, WS,(2008). "Pre-Testing as a Method of Conveying Learning Objectivitas." Journal of Aviation/Aerospace Education \& Research, , 17 (2). https: //doi.org/10.15394/jaaer 1447.

Berry, Thomas, (2008). "Pre-assessment tests." American Journal of Business Education, : DePaul University ,https://files.eric.ed.gov/fulltext/EJ105254 9.pdf.

Campbell, (2002). Multiple Intelegences: Latest Methods sped up Intelligence. Yogyakarta: Inisiati Press, .

Chabot, Mira Costa, Chaffey, and Cabrillo Colleges,(2014). "Boston University study lib.,Pretest and Postest Methods."

https://studylib.net/doc/8246783/choosing-the-right-a ssessment (accessed March Monday, 2019).

Dimitrov, Dimiter \& D Rumrill, Phillip, (2003). "Reading, Mass pretest-posttest Designs and Posttest Measurement_of_Change." 20.159-65.

https://www.researchgate.net/publication/10826237_Prete st (accessed March Sunday, 2019).

Dungana, Silva, (2017). "dmeforpeace Pre-and PostTesting module."

http://www.dmeforpeace.org/wp-content/uploads/2017/06/ 2.820Pre,http://www.wa.gov/esd/training/toolbox/Cre atingTestsGuidelines.pdf. (accessed March Friday, 2019).

Dwi Novianti \& M. Barkah Salim, (2018). "Pengaruh Pemberian Pretest Dan postest Terhadap Pengaruh Kesiapan Hasil Belaja IPA Siswa Kelas VII SMP Metro." FKIP Physical Education University Hamzanwadi jurnal, : Hamzanwadi jurnal, http: // e-journal.hamzanwadi.ac.id/index.php/kpj/article/vie $\mathrm{w} / 754$.

Goleman, Danie .Emotional Intelligence. (Trans): T,(2015). Emotional Intelligence /trans Hermaya. Jakarta: PT.Gramedia Pustaka Utama, .

Hilton, Charlotte, (2015). "The importance of pretesting questionnaires: Scale (ER-QLS." Intern example of cognitive Journal of Social Research Methodology, 2015: 1-15).

http://dx.doi.org/10.1080/13645579.2015.1091640.

Kelly, Melissa, (2019). "Importance-and-uses-of-pretest spretests Effective Tools to Target Instruction. Thought Co, 7674." thoughtco.com/. 2019.

https://www.thoughtco.com/importance-and-uses-ofpretests- (accessed March Monday, 2019).

Lubis, R. R., Irwanto, I., \& Harahap, M. Y. (2019). Increasing Learning Outcomes and Ability Critical Thinking of Students Through Application Problem Based Learning Strategies. International Journal for Educational and Vocational Studies, 1(6). 524-527.

Michael, Delucchi, (2014). "Measuring Student Learning in Social Statistics: A pretestPosttest Study of Knowledge Gain." Posttest Study of Knowledge Gain, American Sociological Association. . Vol. 42 (3) 231-239.http://dx.doi.org/10.1177/0092055.2014.5279 09 (accessed February Monday, 2019).

Moelong, Lexy J, (2007). Metodologi Riset Kualitatif. Bandung: Rosda Karya.

Mulyasa, (2008). Kurikulum Tingkat Satuan Pendidikan. Jakarta: Bumi Aksara, .

Nasution., (1982). Metodologi Riset. Jakarta: Bumi Aksara.

Purwanto, Ngalim, (1998). Prinsip-prinsip Dan Teknik Evaluasi Pengajaran. Bandung: Rosda Karya.

Schaffhauser, Dian, (2018). "Student Privacy for Pre-Test Surveysin SAT and ACT. Privacy-for-pretest-surveys-in-sat-and-act.aspx." Media education publications The Journal and Campus student technology, n.d.: https://thejournal.com/articles/2018/06/22/feds-tackle

Schneider, Jack, (2013). "Remembrance of Things Past: A History of the Socratic the United State." College of the Holy Cross Worcester, Massachusetts, USA,. . https://pdfs.semanticscholar.org/d94c/6283d9793aa0f 53a8b95c980b284f7a8a81c.pdf (accessed February Friday, 2019).

Shivaraju PT, Manu G, Vinaya M, Savkar, (2017). "Evaluating the effectiveness of pre- and post-test models of learning in a medical school." Physiol Pharm. Physiol Pharm (9):947-95

https://www.ejmanager.com/mnstemps/28/28(accessed March Sunday, 2019).

Sudjono, Anas, (1996). Pengantar evaluasi pendidikan. Jakarta: Raja Grafindo Persada, .

Sugiyono, (2005). Memahami Penelitian Kualitatif. Bandung: Alfabeta.

Sugiyono, (2009). Metode Penelitian Kuantitatif Kualitatif, dan $R \& D$. Bandung: Alfabeta, .

Sugiyono, (2014). Metode Penelitian Kuantitatif, Kualitatif, dan R\&D. Bandung: Alfabeta. 